\title{
Addition of Tannin in Lamb Diets after Weaning: Impact on Performance and Hematological and Biochemical Variables
}

\author{
Eduardo Lucianer', Aleksandro Schafer Da Silva², Chrystian Jassana Cazarotto', Davi Fernando Alba', \\ Luiz Gustavo Griss², Aline Zampar², Marcelo Vedovatto ${ }^{3}$ \& Julcemar Dias Kessler ${ }^{2}$
}

\begin{abstract}
Background: In ruminants, the weaning period is a critical phase, because these young animals are allocated to various facilities and receive different feeds. Alternatively, supplements and additives can be used. The tannins are polyphenols produced by plants; constitute a group of complex secondary metabolic factors that inhibit the consumption by herbivores or the development of microbial agents. The objective of this study was to determine whether the addition of condensed tannin extract from quebracho trees (Schinopsis lorentzii) in lamb diets after weaning would have beneficial effects on growth and health.

Materials, Methods \& Results: Forty lambs were assigned randomly to 1 of 4 treatments (10 lambs/treatment): T1 (0\%; control), T2, T3, and T4 was $0.3,0.6$ and $0.9 \%$ of quebracho extract in the diet, respectively. The T2 (0.3\%) lambs had greater body condition scores $(P=0.005)$, and although they did not differ significantly, they had numerically greater body weight $(P=0.067)$ and weight gain $(P=0.072)$, than the control lambs. The anthelmintic and anticoccidial effect was not possible to verify because no animals in any group were naturally infected by helminths or coccidia. The T4 lambs had greater numbers of erythrocytes (days 10 and 40) $[P<0.05]$, greater hemoglobin concentrations (days 10 and 40), and greater numbers of total leukocytes (day 10) as a result of greater numbers of neutrophil at the end of the adaptation period (day 10) compared to T1. The T3 and T4 lambs had greater $(P<0.05)$ serum total protein (days 10 and 40) because of greater concentration of serum globulins (days 10 and 40) compared to T1, suggesting that the addition of tannin stimulated the immune system. The addition of quebracho in the diet affected serum concentrations of glucose, triglycerides, and cholesterol at some times and treatments $(P<0.05)$. However, these changes did not follow a pattern; this finding only suggested that there was an influence on the metabolism of carbohydrates and lipids. The T2 lambs showed no differences on hemogram or serum clinic biochemistries $(P>0.05)$; however, they had a greater body condition scores than $\mathrm{T} 1(P<0.05)$.

Discussion: According to literature, if condensed tannins are supplied in moderate quantities ( $\leq 5 \%$ of diet) to ruminants, they can prevent bloating, increase the supply of undegraded protein in the rumen and improve the use of essential amino acids. It is also known that tannins in diet may increase urea recycling efficiency by increasing the concentration of urea in saliva and salivary flow into the rumen. Studies observed that cattle and sheep given feed containing condensed tannins had higher production of wool, meat, milk, and ovulation rates in females, desirable effects on animal production. According to the literature, dietary supplementation with tannins from chestnut and quebracho ( $2 \mathrm{~g} / \mathrm{kg}$ of feed) to Holstein cattle changed the composition of the ruminal microbiota, particularly the bacteria that degrade fiber and starch, reducing the abundance of Prevotella and Fibrobacter, favoring Ruminococcaceae and other members of the phylum Firmicutes, increasing the $\mathrm{pH}$ and decreasing urease activity in ruminal fluid. Therefore, when tannins are supplemented at low concentrations, they can stimulate the intake and utilization of essential amino acids in the small intestine, increasing performance and exerting an anthelmintic effect. Our study found that the addition of $0.3 \%$ of quebracho in the diet improved lamb growth and health after weaning. It is therefore an additive that can be used to feed lambs in critical post weaning period.
\end{abstract}

Keywords: Additive, feedlot, quebracho extract, weaning, animal health. 


\section{INTRODUCTION}

In ruminants, the weaning period is a critical phase, because these young animals are allocated to various facilities (often in collective pens or paddocks) and receive different feeds (concentrate and roughage instead of milk [7]. Under these conditions, young animals become susceptible to adverse conditions because their active immunity is not completely developed, increasing their susceptibility to diseases [12]. Another important factor is that, in recently weaned animals, the rumen is not completely formed, increasing the probability of digestive disorders [29]. Alternatively, supplements and additives (as ingredients with high concentrations of tannin) can be used.

The tannins are polyphenols produced by plants. They constitute a group of complex secondary metabolic factors that inhibit the consumption by herbivores or the development of microbial agents; they are also responsible for the astringency found in fruits and other parts of the plants [21]. The tannins are classified as condensates, flavonoid polymers (that can be oxidized to acid for anthocyanidins), and hydrolyzable (consist of gallic acid and ellagic esters [25]. In ruminant nutrition, tannins have both beneficial and harmful effects, depending of chemical composition, concentration, physiological state, animal species, environment, and other factors [18]. The negative effects occur when they are given in high concentrations in the diet, thereby decreasing voluntary intake, protein and fiber digestibility, performance (weight gain and production of milk, meat and wool), leading to bloat and death in extremes cases [8]. Therefore, the objective of this study was to determine whether addition of tannin in lamb diets after weaning improves health and growth; a critical moment due to the food transition period and thermal stress.

\section{MATERIALS AND METHODS}

\section{Tannin}

The quebracho extract included $64 \%$ of tannin and was produced by the atomization of quebracho wood (Schinopsis lorentzii).

\section{Animals and experimental design}

The experiment was conducted at a commercial dairy sheep farm in Chapecó, Santa Catarina, Brazil. Forty Lacaune male lambs (60 day of age), were housed in a covered feedlot with wood shavings on the floor and were allocated to 4 pens (1 treatment/pen;
10 lambs/pen; 12 m²/pen) located side-by-side. Each animal was considered an experimental unit, and they were fed with concentrate, hay, and silage, as described in Table 1, formulated according to nutritional requirements for ovines [22]. The study lasted 40 days, with 10 days of adaptation to the treatments and 30 days of data collection. On day 1 , the animals were assigned randomly to 1 of 4 treatments (10 lambs/treatment): $\mathrm{T} 1-0 \%$ (control), T2 - 0.3\%, T3-0.6\%, and T4-0.9\% of quebracho extract in the diet. The quebracho extract was added into the concentrate and homogenized in a manual mixer for $10 \mathrm{~min}$. The same ingredients were used during the 40 days of the experiment; however, the concentrates were prepared at intervals of 8 days.

Body weight

Body weights of the lambs were measured using a digital scale on days 1, 10, 20, 30 and 40 of the study to evaluate weight gain and feed conversion. It is important to note that the days 1 and 10 of the experiment correspond to the beginning and the end of the adaptation period, respectively.

\section{Morphological measures}

The morphological measurements were as follows: length (length of the first thoracic vertebra to the last lumbar vertebra), anterior height (made from the floor following the anterior limb up to the thoracic spine), posterior height (made from the floor until the insertion of the ischium) and thoracic circumference (encircling below the axilla). The data were collected on days $1,10,20,30$ and 40, using a metric tape graduated in centimeters [24].

\section{Intake}

The concentrate, hay (Cynodon spp. cv. Tifton 85 ) and corn silage were provided twice daily. The roughage-to-concentrate ratio was $80.74: 19.26$. The amount of feed provided to the lambs was $2.8 \%$ of the body weight [dry matter (DM) basis] and water was provided ad libitum. Feed intake and orts were weighed with the objective of maintaining $10 \%$ of orts per day.

\section{Feed analysis}

The chemical composition of the diets, concentrate, hay and silage are described in Table 1. Feed samples were oven-dried for $72 \mathrm{~h}$ at $55^{\circ} \mathrm{C}$ and then milled at $1 \mathrm{~mm}$. Parts of the samples were placed in an oven at $105^{\circ} \mathrm{C}$ for $16 \mathrm{~h}$ and then subjected to analysis to determine the following concentrations: DM, ash, 
crude protein (CP), and ethereal extract (EE) [1]; neutral detergent fiber (NDF) and acid detergent fiber (ADF) were determined according to literature [28].

\section{FAMACHA test}

The FAMACHA test was performed to evaluate the degree of anemia on days 1, 10,20,30 and 40 of the experiment. All tests were performed by the same technician, observing the coloration of the conjunctiva of the animal [20].

\section{Body condition score}

The body condition score evaluation was based in a scale of 0 to 5 points (from very thin to very fat), made by palpation of the muscle and adipose cover of the lumbar region of the animals [14]. All evaluations were conducted by the same technician on days 1,10 , 20, 30 and 40 .

\section{Blood and feces collections}

Blood samples were collected on days 1 (beginning of the adaptation period), 10 (end of the adaptation period and beginning of the experimental period), and 40 (end of the experimental period). Blood samples were collected from the jugular vein into blood collection tubes without anticoagulant (for biochemical analysis in serum) and with ethylenediamine tetraacetic acid (EDTA: for hematological analysis). Blood samples without sodium anticoagulant were centrifuged at $2100 \mathrm{~g}$ for $10 \mathrm{~min}$. Serum was harvested and stored at $-20^{\circ} \mathrm{C}$ until further analysis. Blood samples containing EDTA were stored at $4^{\circ} \mathrm{C}$ overnight and hematological analyses were performed within $24 \mathrm{~h}$ of collection.

Fecal samples were collected directly from the rectal ampulla on days 1, 10 and 30, immediately stored on ice, and analyzed within $24 \mathrm{~h}$ after collection.

\section{Hemogram}

Erythrocyte, total leukocyte counts, and hemoglobin $(\mathrm{Hb})$ content were measured using a semi-automated analyzer $\left(\mathrm{Celm}^{\circledR} 530\right)^{1}$. Hematocrit was obtained after capillary centrifugation ( $680 \mathrm{~g}$ for $5 \mathrm{~min}$ ). Leukocyte differential counts were performed in blood smears stained with a commercial dye (Romanowsky method) and viewed with a light microscope at 1000x magnification.

\section{Serum biochemistry}

Total protein (TP), glucose, triglycerides, cholesterol, albumin, and urea were measured using a semi-automated analyzer (BioPlus $\left.2000^{\circledR}\right)^{2}$ with com- mercial kits (Analisa $\left.{ }^{\circledR}\right)^{3}$. Globulin levels were obtained using the following formula: total protein - albumin.

\section{Fecal examination}

The feces were analyzed by the McMaster technique to measure the number of oocysts per gram of feces (EPG) using a saturated sugar solution.

\section{Statistical analysis}

The experimental design was completely randomized, with 4 treatments and 10 replicates. The majority of the blood variables were not normally distributed and therefore were log-transformed. Data of morphology, weight, FAMACHA, body condition score and blood variables were analyzed using comparison of means, performed using two-way ANOVA for comparison between groups and time (repeated measures) and then compared using the Tukey test. The data were analyzed using JMP $8^{4}$ and values were considered significant at $P \leq 0.05$.

\section{RESULTS}

\section{Growth and morphological measures}

There were no differences between treatment groups in terms of feed intake (Table 2) during the entire study $(P>0.05)$. The lambs receiving both treatments consumed more than $89 \%$ of the diet provided daily, with the amounts of orts greater than estimated. Feed conversion also did not differ between treatment groups $(P>0.05)$. The FAMACHA test showed no significant differences between groups and over time $(P>0.05)$. The color of the conjunctiva scored 1 and 2 , considered normal for sheep.

There were no differences between treatment groups in terms of weight $(P=0.54)$, weight gain $(P$ $=0.067)$ and daily weight gain $(P=0.072)$ during the experiment (Figure 1). However, the body condition score was greater in group T2 than in group T1 $(P=$ $0.005)$, with no difference between groups supplemented with tannin (T2, T3, and T4; $P>0.05$ ). There were no differences between treatment groups in terms of morphological variables during the experimental period (Table 3 ).

\section{Hemogram}

The hemograms of the lambs are presented in Table 4. Effects of treatment were detected on day 10 for hematocrit, hemoglobin, number of total 
erythrocytes and total leukocytes. T4 lambs had higher levels than T1 lambs. On day 40, hemoglobin concentration and the number of erythrocytes were greater in $\mathrm{T} 4$ than in T1. The greater number of leukocytes on day 10 was explained by the greater number of neutrophils in T4 lambs. The numbers of lymphocytes, monocytes, and eosinophils did not differ between groups.

Over time, the hematocrit, concentration of hemoglobin, and erythrocytes varied in the T1 group, and these parameters were lower on $\mathrm{d} 10$ than at other collection times. In T2, the hematocrit decreased from days 1 to 10 , and the number of erythrocytes increased from days 1 to 40. In T4, the number of total leukocytes increased from day 1 to 40 as a consequence of the increased numbers of neutrophils and lymphocytes. The number of eosinophils and monocytes did not differ over time (Table 4).

\section{Serum biochemistry}

The serum biochemical variables are displayed in Table 5. Effects of treatment were detected for total protein and globulin, and the concentrations of these were greater in T3 and T4 than in T1 on days 10 and 40. Effects of treatment were not detected for albumin or urea. The concentration of glucose and triglycerides differed between groups. The T4 lambs had lower concentrations of glucose on day 10, and greater concentrations on day 40, than T1 lambs. The T4 lambs had greater concentrations of triglycerides on day 10 , and lower concentrations on day 40, than did T1 lambs Concentrations of cholesterol were greater in $\mathrm{T} 3$ than in $\mathrm{T} 1$ lambs.

Over time, the concentrations of total protein decreased as a consequence of reduced concentrations of globulins in T1 lambs (days 1 to 10). However, in groups T2, T3 and T4, the concentrations of total protein and globulins increased from day 1 to 40 . Over time, the concentrations of albumin and cholesterol did not differ between groups. Over time, the serum concentration of urea increased in T3 (days 1 to 40). Over time, the concentration of serum glucose was lower in T1 and T2 lambs (days 10 to 40). Finally, over time, serum concentrations of triglycerides increased in $\mathrm{T} 1$ (days 10 to 40), T2 (days 1 to 40) and T3 (days 1 to 10 and days 1 to 40; Table 5).

\section{Fecal examination}

No eggs, cysts or parasitic oocysts were observed in the fecal samples collected on days 1, 10 and 40 in any animal.

\section{DISCUSSION}

Quebracho extracts that rich in tannins were provided to lambs after weaning in summer in this study, as in other studies [10,30]. Tannins are common components in many vegetables; however, they are generally found in low concentrations in feeds consumed by ruminants. The digestive system of these animals is prepared to avoid negative effects during the absorption process, because high doses can intoxicate sheep [13]. Condensed tannins undergo hydrolysis in the ruminal environment via the flavonol group, the basic unit capable of forming bonds with other molecules; there is complexation of tannin with dietary protein; and as a result, the complexed protein is not degraded in the rumen and is not used by the ruminal bacteria [19]. Consequently, the protein bound with tannin enters the small intestine, where at $\mathrm{pH} 3.5$ to 8 it becomes stable, allowing the enzymatic action of intestinal proteases [3]. Tannins from vegetables in food boluses bind free radicals and other molecules, and are then excreted. This protein binding inhibits adhesion to cell walls of the intestine, a process that improves nutrient utilization and the immune response [5].

Recent studies showed that inclusion of quebracho in lamb diets improved meat quality, reduced lipid peroxidation [16], altered meat color favorably, and prolonged shelf life [17]. Furthermore, tannin supplementation in lamb diets did not affect the concentration of the main classes of fatty acids in the meat or peroxidability of the marbling fat [30]. In the present study, the effects of supplementation on meat quality were not evaluated; however, there were effects on growth and health in lambs after weaning.

In the present study, supplementation with $0.3 \%$ quebracho extract improved lamb body condition scores, as well as their tendency to increase weight $(P=0.06)$. The other concentrations of tannin did not affect growth, because the results were similar to those of the control group (not supplemented). It is not possible to affirm this, however, if the experimental length were longer, it is possible that we could have observed effects of supplementation on body weight and weight gain, as were observed by researchers using $0.8 \%$ of quebracho in lamb diets [9]. A similar result was also reported when quebracho was included at $40 \mathrm{~g}$ of quebracho/kg (corresponding to $0.4 \%$ ) of dry matter, significantly increasing the average daily gain in lambs, compared to control diets [15]. Researchers 

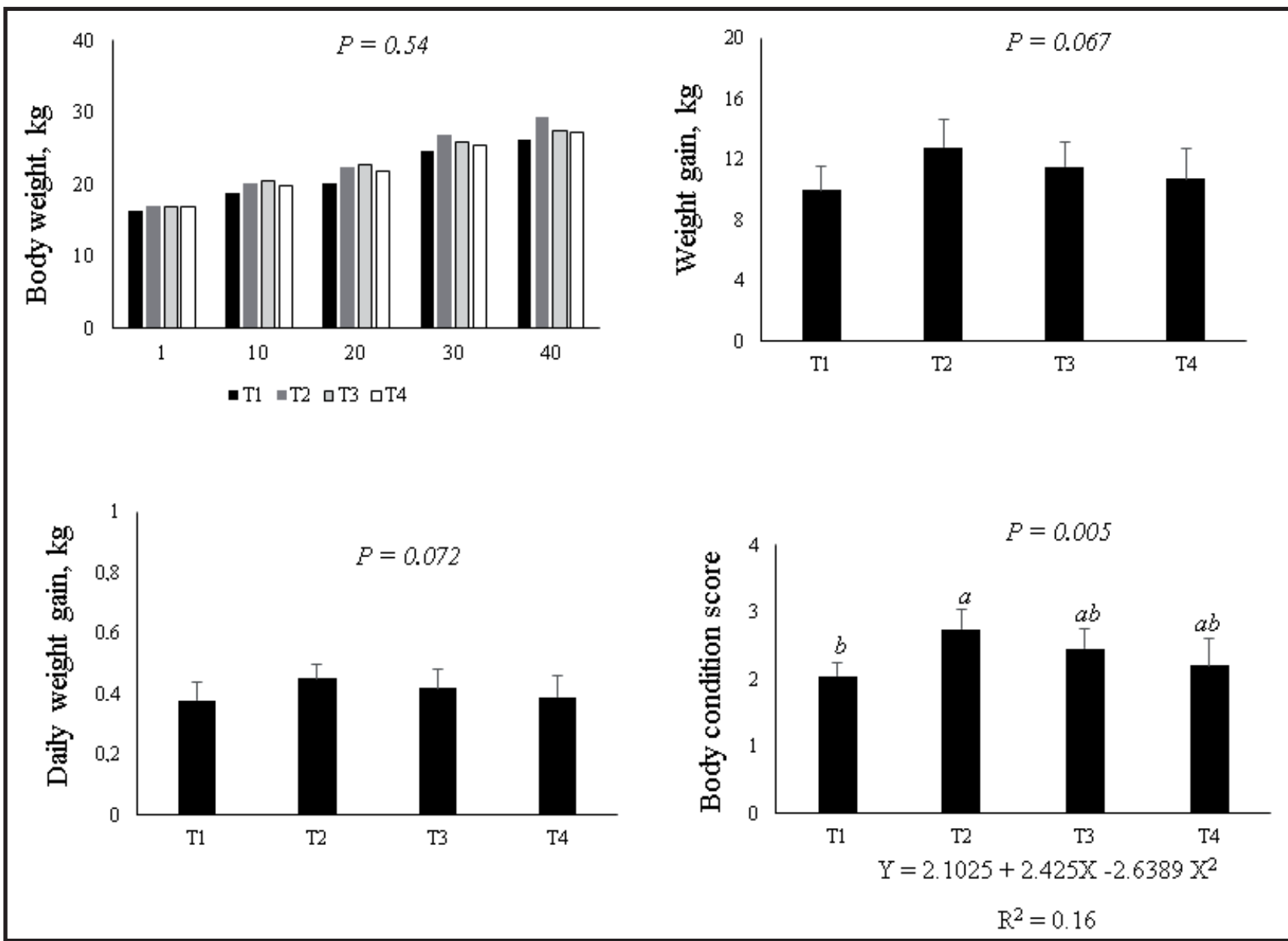

Figure 1. Body weight (days 1, 10, 20, 30 and 40), weight gain (days 1 to 40), daily weight gain and body condition score of lambs supplemented with quebracho extract containing tannin during the summer. The treatments consisted of the inclusion of $0 \%$ (T1 - control), $0.3 \%$ (T2), $0.6 \%$ (T3) and $0.9 \%$ (T4) of quebracho extract in the diets.

Table 1. Chemical composition of the diet and ingredients supplied to lambs during the $40 \mathrm{~d}$ experiment in the diets containing $0 \%$ (T1 - control), $0.3 \%$ (T2), $0.6 \%$ (T3) and $0.9 \%$ (T4) of quebracho extract.

\begin{tabular}{ccccccc}
\hline Feeds & \multicolumn{3}{c}{ Natural matter } & \multicolumn{3}{c}{ Dry matter } \\
\hline Concentrate ${ }^{1}$, kg/d per group & \multicolumn{3}{c}{2.19} & & 1.94 \\
Silage, kg/d per group & \multicolumn{2}{c}{8.68} & & 6.17 & 0.22 \\
Hay, kg/d per group & & \multicolumn{2}{c}{0.51} & & 88.91 & 88.32 \\
\hline Composition analyzed & Hay & Silage & Concentrate: T1 & Concentrate: T2 & Concentrate: T3 & Concentrate: T4 \\
\hline Dry matter, \% & 71.16 & 32.77 & 87.77 & 89.03 & 7.78 & 8.09 \\
Ashes, \% & 11.18 & 5.61 & 7.93 & 7.12 & 15.14 & 15.02 \\
Crude protein, \% & 10.80 & 7.17 & 15.14 & 14.99 & 3.40 & 3.38 \\
Ethereal extract, \% & 0.48 & 2.39 & 2.95 & 3.56 & 3.31 & 3.29 \\
ADF, \% & 33.27 & 19.65 & 3.28 & 3.73 & 11.41 & 10.76 \\
NDF, \% & 68.20 & 45.43 & 11.68 & 11.50 & 3.11 & 3.11 \\
\hline
\end{tabular}

${ }^{1}$ Concentrate ingredients: ground corn (74.25\%); soybean meal (20.88\%); premix (2.78\%); calcitic limestone (1.39\%) \& ammonium chloride (0.69). Composition of the premix: phosphorus (min $55 \mathrm{~g} / \mathrm{kg}$ ); calcium (min. $215 \mathrm{~g} / \mathrm{kg}$, max $225 \mathrm{~g} / \mathrm{kg}$ ); sulfur (min $12 \mathrm{~g} / \mathrm{kg}$ ); sodium (min $80 \mathrm{~g} / \mathrm{kg}$ ); cobalt (min $60 \mathrm{mg} / \mathrm{kg}$ ); chromium (min $12 \mathrm{mg} / \mathrm{kg}$ ); iron (min $142 \mathrm{mg} / \mathrm{kg}$ ); iodine (min $100 \mathrm{mg} / \mathrm{kg}$ ); magnesium (min $14 \mathrm{mg} / \mathrm{kg}$ ); manganese (min $155 \mathrm{mg} /$ $\mathrm{kg}$ ); selenium ( $\min 22 \mathrm{mg} / \mathrm{kg}$ ); vitamin A (min 20,000 IU/kg); vitamin D (min 4,000 IU/kg); vitamin E (min $550 \mathrm{IU} / \mathrm{kg}$ ) \& fluorine (max $550 \mathrm{mg} / \mathrm{kg}$ ). 
E. Lucianer, A.S. Da Silva, C.J. Cazarotto, et al. 2019. Addition of Tannin in Lamb Diets after Weaning: Impact on Performance and Hematological and Biochemical Variables.

Table 2. Feed intake and feed conversion of lambs receiving diets containing 0\% (T1 - control), 0.3\% (T2), 0.6\% (T3) and 0.9\% (T4) of quebracho extract.

\begin{tabular}{cccccc}
\hline Variable & Days & T1: Control & T2: $0.3 \%$ EQ-T & T3: 0.6 \% EQ-T & T4: 0.9 \% EQ-T \\
\hline Average & 1 & 7.96 & 8.77 & 7.15 & 6.56 \\
Intake, & 10 & 7.45 & 8.81 & 8.66 & 7.78 \\
kg/d per group & 20 & 7.32 & 8.83 & 9.89 & 8.87 \\
& 30 & 9.37 & 10.26 & 10.89 & 9.94 \\
& 40 & 9.93 & 11.43 & 12.27 & 11.50 \\
\hline Feed & 1 & 0.49 & 0.52 & 0.42 & 0.39 \\
Conversion, & 10 & 0.40 & 0.44 & 0.42 & 0.39 \\
kg/d per group & 20 & 0.36 & 0.40 & 0.44 & 0.41 \\
& 30 & 0.38 & 0.38 & 0.42 & 0.39 \\
& 40 & 0.38 & 0.39 & 0.45 & 0.42 \\
\hline
\end{tabular}

There was no difference between groups for these two variables at the analyzed time points $(P>0.05)$.

Table 3. Measurements of morphological characteristics of lambs receiving diets containing 0\% (T1 - control), 0.3\% (T2), 0.6\% (T3) and $0.9 \%$ (T4) of quebracho extract.

\begin{tabular}{|c|c|c|c|c|c|c|}
\hline Variable & Days & $\begin{array}{c}\mathrm{T} 1: \\
\text { Control }\end{array}$ & $\begin{array}{c}\mathrm{T} 2: \\
0.3 \% \text { EQ-T }\end{array}$ & $\begin{array}{c}\text { T3: } \\
0.6 \% \text { EQ-T }\end{array}$ & $\begin{array}{c}\text { T4: } \\
0.9 \% \text { EQ-T }\end{array}$ & $P$-value \\
\hline \multirow[t]{5}{*}{ Length, $\mathrm{cm}$} & 1 & 46.30 & 45.20 & 47.15 & 45.75 & 0.73 \\
\hline & 10 & 48.70 & 49.40 & 51.30 & 49.65 & 0.77 \\
\hline & 20 & 51.20 & 51.90 & 51.40 & 50.10 & 0.83 \\
\hline & 30 & 53.05 & 53.70 & 52.60 & 51.30 & 0.83 \\
\hline & 40 & 54.00 & 54.30 & 54.40 & 51.55 & 0.60 \\
\hline \multirow[t]{5}{*}{ Height of the anterior, $\mathrm{cm}$} & 1 & 53.90 & 53.70 & 53.60 & 52.70 & 0.89 \\
\hline & 10 & 54.55 & 54.20 & 54.10 & 54.40 & 0.76 \\
\hline & 20 & 54.65 & 54.60 & 57.05 & 56.30 & 0.98 \\
\hline & 30 & 55.55 & 55.55 & 59.35 & 59.05 & 0.84 \\
\hline & 40 & 56.55 & 57.30 & 60.60 & 60.30 & 0.64 \\
\hline \multirow[t]{5}{*}{ Height of the posterior, $\mathrm{cm}$} & 1 & 47.40 & 46.80 & 47.50 & 46.90 & 0.87 \\
\hline & 10 & 48.60 & 49.15 & 49.25 & 48.20 & 0.78 \\
\hline & 20 & 49.35 & 49.70 & 49.70 & 48.70 & 0.75 \\
\hline & 30 & 51.10 & 50.55 & 51.55 & 50.55 & 0.59 \\
\hline & 40 & 51.70 & 51.90 & 52.85 & 51.10 & 0.84 \\
\hline \multirow[t]{5}{*}{ Thoracic circumference, $\mathrm{cm}$} & 1 & 55.90 & 57.25 & 54.00 & 56.40 & 0.12 \\
\hline & 10 & 60.35 & 61.00 & 58.45 & 59.95 & 0.23 \\
\hline & 20 & 57.95 & 61.30 & 60.35 & 59.45 & 0.15 \\
\hline & 30 & 61.70 & 63.20 & 58.50 & 63.40 & - \\
\hline & 40 & 63.60 & 65.90 & 64.40 & 63.50 & 0.41 \\
\hline
\end{tabular}

$P \leq 0.05$ differs statistically between groups (Different lowercase letters in the same row show which group differs). $P \leq 0.05$ also shows the difference over time in each group (different capital letters [underwritten] in the same column show which d differs in the same treatment). 
E. Lucianer, A.S. Da Silva, C.J. Cazarotto, et al. 2019. Addition of Tannin in Lamb Diets after Weaning: Impact on Performance and Hematological and Biochemical Variables.

Acta Scientiae Veterinariae. 47: 1709.

Table 4. Hemogram of lambs receiving diets containing 0\% (T1 - control), 0.3\% (T2), 0.6\% (T3) and 0.9\% (T4) of quebracho extract.

\begin{tabular}{|c|c|c|c|c|c|c|}
\hline Variable & Days & T1: Control & T2: $0.3 \%$ EQ-T & T3: $0.6 \%$ EQ-T & T4: $0.9 \%$ EQ-T & $P$-value \\
\hline Erythrocytes, & 1 & АB $6.3(1.98)$ & $7.3(2.2)$ & $5.7(1.1)$ & в5.4 (1.1) & $>0.05$ \\
\hline \multirow[t]{3}{*}{$\times 10^{6} / \mu \mathrm{L}$} & 10 & ${ }^{\mathrm{AB}} 4.3(0.2)^{\mathrm{b}}$ & $5.5(0.9)^{\mathrm{ab}}$ & $5.9(1.1)^{\mathrm{ab}}$ & $\mathrm{AB} 7.1(1.7)^{\mathrm{a}}$ & $<0.001$ \\
\hline & 40 & ${ }^{\mathrm{A}} 6.2(0.5)^{\mathrm{b}}$ & $6.8(0.6)^{\mathrm{ab}}$ & $7.0(1.4)^{\mathrm{ab}}$ & A9.1 (1.9) & $<0.001$ \\
\hline & $P$-value & $<0.001$ & $>0.05$ & $>0.05$ & $<0.001$ & \\
\hline Hematocrit, & 1 & А38.3 (1.7) & A41.8 (4.2) & $40(3.7)$ & $39.6(4.0)$ & $>0.05$ \\
\hline \multirow[t]{3}{*}{$\%$} & 10 & ${ }^{\text {в}} 31.3(3.5)^{\text {b }}$ & в $33.5(4.5)^{\mathrm{ab}}$ & $38.1(6.3)^{\mathrm{ab}}$ & $39.0(2.9)^{\mathrm{a}}$ & $<0.001$ \\
\hline & 40 & A440.1 (3.9) & ${ }^{\mathrm{A}} 42.6(4.5)$ & $35.1(8.4)$ & $37.8(1.9)$ & $>0.05$ \\
\hline & $P$-value & $<0.001 *$ & $<0.05$ & $>0.05$ & $>0.05$ & \\
\hline \multirow{4}{*}{$\begin{array}{l}\text { Hemoglobin, } \\
\text { g/dL }\end{array}$} & 1 & ${ }^{\mathrm{A}} 11.2(0.6)$ & $11.5(0.9)$ & $10.7(0.5)$ & $10.7(0.8)$ & $\geq 0.05$ \\
\hline & 10 & в9.7 $(0.4)^{\text {b }}$ & $10.8(0.6)^{\mathrm{ab}}$ & $10.5(1.4)^{\mathrm{ab}}$ & $10.9(0.7)^{\mathrm{a}}$ & $<0.01$ \\
\hline & 40 & ${ }^{\mathrm{B}} 10.3(0.3)^{\mathrm{b}}$ & $10.8(0.8)^{\mathrm{ab}}$ & $10.4(0.6)^{\mathrm{ab}}$ & $11.1(0.6)^{\mathrm{a}}$ & $<0.05$ \\
\hline & $P$-value & $<0.001$ & $>0.05$ & $>0.05$ & $>0.05$ & \\
\hline \multirow{4}{*}{$\begin{array}{l}\text { Leukocytes, } \\
\times 10^{3} / \mu \mathrm{L}\end{array}$} & 1 & $7.7(1.7)$ & $7.6(1.7)$ & $6.6(3.3)$ & ${ }^{\mathrm{B}} 6.0(1.9)$ & $>0.05$ \\
\hline & 10 & $6.2(0.9)^{\mathrm{b}}$ & $6.7(1.4)^{\mathrm{ab}}$ & $8.3(1.7)^{\mathrm{ab}}$ & АB9. $8(2.2)^{\mathrm{a}}$ & $<0.001$ \\
\hline & 40 & 13.(8.0) & $10.6(3.6)$ & $11.8(3.3)$ & ${ }^{\mathrm{A}} 14.4(4.8)$ & $>0.05$ \\
\hline & $P$-value & $>0.05$ & $>0.05$ & $>0.05$ & $<0.001$ & \\
\hline \multirow{4}{*}{$\begin{array}{l}\text { Neutrophils, } \\
\times 10^{3} / \mu \mathrm{L}\end{array}$} & 1 & $2.97(0.5)$ & $3.48(1.5)$ & $3.22(2.0)$ & в $2.22(0.28)$ & $>0.05$ \\
\hline & 10 & $2.21(0.8)^{\mathrm{b}}$ & $2.32(0.7)^{\mathrm{b}}$ & $4.2(1.0)^{\mathrm{a}}$ & ${ }^{\mathrm{AB}} 4.5(1.3)^{\mathrm{a}}$ & $<0.001$ \\
\hline & 40 & $5.43(3.8)$ & $4.45(2.8)$ & $5.41(3.07)$ & А7.92 (3.8) & $>0.05$ \\
\hline & $P$-value & $>0.05$ & $>0.05$ & $>0.05$ & $<0.001$ & \\
\hline \multirow{4}{*}{$\begin{array}{l}\text { Lymphocytes, } \\
\quad \times 10^{3} / \mu \mathrm{L}\end{array}$} & 1 & $4.39(1.3)$ & $3.93(0.9)$ & в3.13 (1.1) & в $2.95(0.9)$ & $>0.05$ \\
\hline & 10 & $3.98(1.2)$ & $3.77(1.1)$ & АВ 3.94 (1.0) & $\mathrm{AB} 4.80(1.3)$ & $>0.05$ \\
\hline & 40 & $7.58(4.3)$ & $5.86(1.4)$ & А $5.46(1.7)$ & А $5.9(1.4)$ & $>0.05$ \\
\hline & $P$-value & $>0.05$ & $>0.05$ & $<0.05$ & $<0.01$ & \\
\hline \multirow{4}{*}{$\begin{array}{c}\text { Monocytes, } \\
\times 10^{3} / \mu \mathrm{L}\end{array}$} & 1 & $0.41(0.2)$ & $0.26(0.07)$ & $0.27(0.2)$ & $0.17(0.1)$ & $>0.05$ \\
\hline & 10 & $0.11(0.3)$ & $0.48(0.3)$ & $0.2(0.1)$ & $0.36(0.07)$ & $>0.05$ \\
\hline & 40 & $0.68(0.5)$ & $0.23(0.2)$ & $0.94(1.0)$ & $0.52(0.3)$ & $>0.00$ \\
\hline & $P$-value & $>0.05$ & $>0.05$ & $>0.05$ & $>0.05$ & \\
\hline \multirow{4}{*}{$\begin{array}{c}\text { Eosinophils, } \\
\times 10^{3} / \mu \mathrm{L}\end{array}$} & 1 & $0.0(0.0)$ & $0.0(0.0)$ & $0.0(0.0)$ & $0.0(0.0)$ & - \\
\hline & 10 & $0.05(0.09)$ & $0.11(0.1)$ & $0.0(0.0)$ & $0.15(0.1)$ & $>0.05$ \\
\hline & 40 & $0.08(1.0)$ & $0.09(0.08)$ & $0.08(0.09)$ & $0.05(0.08)$ & $>0.05$ \\
\hline & $P$-value & $>0.05$ & $>0.05$ & $>0.05$ & $>0.05$ & \\
\hline
\end{tabular}

$P \leq 0.05$ differs statistically between groups (Different lowercase letters in the same row show which group differ). $P \leq 0.05$ also shows the difference over time in each group (different capital letters [underwritten] in the same column show which d differ in the same treatment). 
Table 5. Serum clinical biochemistry of lambs receiving diets containing 0\% (T1 - control), 0.3\% (T2), 0.6\% (T3) and 0.9\% (T4) of quebracho extract.

\begin{tabular}{|c|c|c|c|c|c|c|}
\hline Variable & Days & T1: Control & T2: $0.3 \%$ EQ-T & T3: $0.6 \%$ EQ-T & T4: $0.9 \%$ EQ-T & $P$-value \\
\hline \multirow{4}{*}{$\begin{array}{l}\text { Total protein, } \\
\text { g/dL }\end{array}$} & 1 & A5 $5.53(0.6)$ & ${ }^{\mathrm{AB}} 4.66(0.8)$ & в4.97 (0.5) & в4.44 (1.4) & $>0.05$ \\
\hline & 10 & ${ }^{\mathrm{B}} 4.31(0.3)^{\mathrm{b}}$ & в $4.32(0.3)^{\mathrm{b}}$ & AB5 $5.37(0.6)^{\mathrm{a}}$ & AB $5.36(0.5)^{\mathrm{a}}$ & $<0.001$ \\
\hline & 40 & ${ }^{\mathrm{A}} 5.45(0.2)^{\mathrm{b}}$ & A5.97 $(0.1)^{\mathrm{ab}}$ & ${ }^{\mathrm{A}} 6.43(0.4)^{\mathrm{a}}$ & ${ }^{\mathrm{A}} 6.22(0.4)^{\mathrm{a}}$ & $<0.001$ \\
\hline & P-value & $<0.001$ & $<0.001$ & $<0.001$ & $<0.05$ & \\
\hline \multirow{4}{*}{$\begin{array}{l}\text { Albumin, } \\
\text { g/dL }\end{array}$} & 1 & $2.51(0.2)$ & $2.41(0.15)$ & $2.59(0.14)$ & $2.30(0.7)$ & $>0.05$ \\
\hline & 10 & $2.36(0.29)$ & $2.22(0.23)$ & $1.95(0.3)$ & $1.99(0.3)$ & $>0.05$ \\
\hline & 40 & $2.56(0.22)$ & $2.46(0.12)$ & $2.35(0.23)$ & $2.18(0.28)$ & $>0.05$ \\
\hline & $P$-value & $>0.05$ & $>0.05$ & $>0.05$ & $>0.05$ & \\
\hline \multirow{4}{*}{$\begin{array}{l}\text { Globulin, } \\
\text { g/dL }\end{array}$} & 1 & A3.02 (0.8) & $2.25(0.8)$ & ${ }^{\text {в}} 2.38(0.5)$ & ${ }^{\text {в}} 2.15(0.6)$ & $>0.05$ \\
\hline & 10 & в $1.95(0.3)^{\mathrm{b}}$ & $2.1(0.2)^{\mathrm{b}}$ & AB3.39 $(0.7)^{\mathrm{a}}$ & AB3.37 $(0.5)^{\mathrm{a}}$ & $<0.001$ \\
\hline & 40 & ${ }^{\mathrm{A}} 2.89(0.3)^{\mathrm{b}}$ & $3.51(0.2)^{\mathrm{ab}}$ & А $4.08(0.5)^{\mathrm{a}}$ & А $4.04(0.6)^{\mathrm{a}}$ & $<0.01$ \\
\hline & P-value & $<0.001$ & $>0.05$ & $<0.001$ & $<0.001$ & \\
\hline \multirow{4}{*}{$\begin{array}{l}\text { Urea, } \\
\mathrm{mg} / \mathrm{dL}\end{array}$} & 1 & $13.8(3.8)$ & $20.0(6.0)$ & в $10.8(5.8)$ & $12.5(6.1)$ & $>0.05$ \\
\hline & 10 & $19.9(5.8)$ & $10.5(8.9)$ & ${ }^{\mathrm{AB}} 12.4$ (7.6) & $17.5(5.8)$ & $>0.05$ \\
\hline & 40 & $19.3(3.3)$ & $17.7(5.3)$ & ${ }^{\mathrm{A}} 19.0(3.2)$ & $19.9(5.1)$ & $>0.05$ \\
\hline & P-value & $>0.05$ & $>0.05$ & $<0.05$ & $>0.05$ & \\
\hline \multirow{4}{*}{$\begin{array}{l}\text { Glucose, } \\
\mathrm{mg} / \mathrm{dL}\end{array}$} & 1 & ${ }^{\mathrm{AB}} 83.9(15.6)$ & ${ }^{\mathrm{AB}} 82.8(19.5)$ & $81.3(12.3)$ & $70.6(2.1)$ & $>0.05$ \\
\hline & 10 & A88.0 (10.0) & A91.1 $(14.2)^{\mathrm{a}}$ & $82.1(10.5)^{\mathrm{ab}}$ & $72.8(8.4)^{\mathrm{b}}$ & $<0.01$ \\
\hline & 40 & В71.0 $(4.8)^{\mathrm{b}}$ & ${ }^{\mathrm{B}} 66.7(12.0)^{\mathrm{b}}$ & $89.2(7.6)^{\mathrm{a}}$ & $85.3(5.1)^{\mathrm{a}}$ & $<0.001$ \\
\hline & $P$-value & $<0.001$ & $<0.001$ & $>0.05$ & $>0.05$ & \\
\hline \multirow{4}{*}{$\begin{array}{c}\text { Triglycerides, } \\
\text { mg/dL }\end{array}$} & 1 & $\mathrm{AB} 23.2(8.9)$ & в $18.9(5.0)$ & в $18.9(6.2)$ & $22.5(6.6)$ & $>0.05$ \\
\hline & 10 & 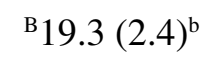 & ${ }^{\mathrm{AB}} 23.3(6.2)^{\mathrm{ab}}$ & ${ }^{\mathrm{A}} 28.4(5.1)^{\mathrm{a}}$ & $29.5(5.5)^{\mathrm{a}}$ & $<0.001$ \\
\hline & 40 & A33.8 $(4.6)^{\mathrm{a}}$ & ${ }^{\mathrm{A}} 30.3(7.2)^{\mathrm{ab}}$ & ${ }^{\mathrm{A}} 27.3(4.3)^{\mathrm{ab}}$ & $24.5(1.2)^{b}$ & $<0.001$ \\
\hline & $P$-value & $<0.001$ & $<0.01$ & $<0.05$ & $>0.05$ & \\
\hline \multirow{4}{*}{$\begin{array}{l}\text { Cholesterol, } \\
\text { mg/dL }\end{array}$} & 1 & $55.4(13.0)$ & $51.2(6.4)$ & $53.4(1.8)$ & $45.1(14.3)$ & $>0.05$ \\
\hline & 10 & $45.4(10.1)^{\mathrm{b}}$ & $46.8(8.29)^{\mathrm{ab}}$ & $62.5(5.4)^{\mathrm{a}}$ & $55.8(6.1)^{\mathrm{ab}}$ & $<0.05$ \\
\hline & 40 & $51.3(7.6)$ & $50.7(6.3)$ & $60.1(1.1)$ & $51.6(7.1)$ & $>0.05$ \\
\hline & P-value & $>0.05$ & $>0.05$ & $>0.05$ & $>0.05$ & \\
\hline
\end{tabular}

$P \leq 0.05$ differs statistically between groups (Different lowercase letters in the same row show which group differ). $P \leq 0.05$ also shows the difference over time in each group (different capital letters [underwritten] in the same column show which d differ in the same treatment).

observed that the addition of chestnut tannins $(0.5$ and $1 \%$ ) increased lamb growth under heat stress [16]. The opposite occurred when $4 \%$ chestnut tannin was added, with reduced growth rate, final weight, carcass weight and feed intake [30].

Tannin supplementation increased dry matter intake as well as average daily gain in cattle in a feedlot (fattening period) [27]. According to these authors, the source of supplemented tannin (condensed versus hydrolyzable) had a minimal effect on overall growth.
In the present study, despite the fact that there was no significant difference, lambs fed with $0.3 \%$ of quebracho extract had $30 \%$ greater weight gain than the control group, which economically could be positive and important during summer. To confirm this result, further research should be conducted, following animal development until slaughter.

Concentrations of 0.3 and $0.6 \%$ of quebracho extract did not affect erythropoiesis, whereas $0.9 \%$ increased the number of erythrocytes and hemato- 
crit, for unknown reasons. Higher concentrations of erythrocytes are generally good effect for an animal during summer, because this allows better tissue oxygenation; nevertheless, it may have been a compensatory effect. Perhaps the concentration of $0.9 \%$ of tannin negatively affected metabolism, and the increase was a compensatory response to minimize these effects. According to the literature, some types of tannins may protect erythrocytes in conditions of oxidative stress $[11,23]$; this could also explain why the concentration of erythrocytes was greater in the lambs that received the highest concentration of tannin.

The addition of $0.3 \%$ of quebracho did not affect the hemogram; however, the higher doses $(0.6$ and $0.9 \%$ ) caused leukocytosis because of neutrophilia. The primary reasons for increased concentrations of neutrophils are bacterial and fungal infections; however, this was probably not the cause in this study, because tannins exert antimicrobial effects. There are other causes of neutrophilia, not explained by diets containing tannin, as previously reported in lambs supplemented with chestnut tannins [16]. Researchers reported that quebracho tannins stimulated the immune response and caused protective effects on the intestinal mucosa in sheep experimentally infected with gastrointestinal parasites [26]. Researchers, using aqueous extracts of Psittacanthus plagiophyllus containing $5.39 \%$ of tannins, reported potent anti-inflammatory effects, reducing the total count of leukocytes and lymphocytes in a model of inflammation induced by carrageenan [4]. In another study, the supplementation with quebracho extract $(0.5$ and $1 \%)$ promoted anti-inflammatory effects on leukocytes, and the concentration of globulins increased, stimulating the immune response, similar to what was observed in the present study with the greater doses of tannins.

In the present study, the inclusion of quebracho in lamb diets affected variables related to the metabolism of carbohydrate and lipids. By contrast, in another study, the addition of tannins (from chestnut or quebracho) in sheep diets did not affect these variables [6]. Addition of tannins in chicken diets decreased cholesterol levels in the eggs [2]. The mechanisms of these changes, as well as those of the fluctuations, should be investigated in future studies. It is important to emphasize that the addition of $0.3 \%$ of quebracho did not affect blood variables; however, this supplementation increased body condition scores and tended to increase weight gain.

\section{CONCLUSION}

Addition of $0.3 \%$ quebracho extract in lamb diets after weaning in summer increased body condition scores. However, quebracho extract did not affect intake, feed conversion, or growth in lambs. The greater level $(0.9 \%)$ of tannin stimulated erythropoiesis, as well as leukocytosis as a consequence of neutrophilia. Supplementation with 0.6 and $0.9 \%$ of quebracho extract stimulated lymphocytosis and consequently increased the concentration of globulin, characterized as a proinflammatory effect of tannin supplementation. The addition of tannin in lamb diets affected the metabolism of carbohydrates and lipids at the end of the adaptation period; that is, the serum concentration of glucose decreased, and the serum concentration of triglycerides and cholesterol increased. Changes in these variables were observed after 40 days of supplementation, but they differed from those observed on day 10. In general, the addition of tannin in lamb diets tended to increase weight gain, improved body condition score, and altered blood variables, and the dose of $0.3 \%$ of quebracho extract had beneficial effects in lambs after weaning in hot season.

\section{MANUFACTURERS}

${ }^{1}$ Celm Cia. Equipadora de Laboratórios Modernos. Barueri, SP, Brazil. ${ }^{2}$ Bioplus Produtos para Laboratórios Ltda. Barueri, SP, Brazil. ${ }^{3}$ Gold Analisa Diagnóstica. Belo Horizonte, MG, Brazil.

${ }^{4}$ SAS Institute Inc. Cary, NC, USA.

Acknowledgements. We thank Cabanha Chapecó that made the animals available and the facility for this study. We also thank CAPES, CNPq and Fapesc (PAP 2017TR745) for financial support.

Ethical approval. The study was approved by the Committee of Ethics in the Use of Animals of the Universidade do Estado de Santa Catarina (CEUA / UDESC) under number 1923240318.

Declaration of interest. The authors report no conflicts of interest. The authors alone are responsible for the content and writing of paper. 


\section{REFERENCES}

1 AOAC. 2000. Association of official Analytic Chemists. Official Methods of Analysis. Washington: AOAC, 1018p.

2 Antongiovanni M., Minieri S., Buccioni A. \& Galigani I. 2015. Effect of a tannin from chestnut wood (Castanea sativa Miller) on cholesterol and fatty acids of eggs. European Symposium on the Quality of Poultry Meat. 22(1): 5236.

3 Barry T.N. \& Duncan S.J. 1984. The role of condensed tannins in the nutritional value of Lotus pedunculatus for sheep: 1 Voluntary intake. British Journal of Nutrition. 51(4): 485-491.

4 Bezzera A.N.S., Massing L.T., Oliveira R.B. \& Mourão R.H.V.2017. Standardization and anti-inflammatory activity of aqueous extract of Psittacanthus plagiophyllus Eichl. (Loranthaceae). Journal of Ethnopharmacology. 202(3): 234-240.

5 Butter N.L., Dawson J.M., Wakelin D. \& Buttery P.J. 2000. Effect of dietary tannin and protein concentration on nematode infection (Trichostrongylus colubriformis) in lambs. Journal of Agricultural Science. 134(1): 89-99.

6 Buccioni A., Pauselli M., Minieri S., Roscini V., Manneli F., Rapaccini S. \& Mele M. 2017. Chestnut or quebracho tannins in the diet of grazing ewes supplemented with soybean oil: Effects on animal performances, blood parameters and fatty acid composition of plasma and milk lipids. Small Ruminant Research. 153(1): 23-30.

7 Cazarotto C.J., Kessler J.D. \& Da Silva A.S. 2019. Nutraceutical effect of trace elements as additional injectable doses to modulate oxidant and antioxidant status, and improves the quality of lamb meat. Biological Trace Element Research. 191(1): 115-125

8 Cordão M.A., Pereira-Filho J.M., Bakke O.A. \& Bakke I.A. 2010. Taninos e seus efeitos na alimentação animal: Revisão bibliográfica. Pubvet. 4(32): 925.

9 Dawson L.E.R., McCoy M.A., Edgar H.W.J. \& Carson A.F. 2011. Effect of concentrate supplementation at pasture and inclusion of condensed tannins (Quebracho) in concentrates on lamb performance and faecal egg and worm counts. Livestock Science. 135(2): 205-214.

10 Douglas G.B., Wang Y., Waghorn G.C., Barry T.N., Purchas R.W., Foote A.G. \& Wilson G.F. 1995. Live weight gain and wool production of sheep grazing Lotus corniculatus and lucerne (Medicago sativa). New Zeal Journal Agriculture Research. 38(1): 95-104.

11 Fedeli D., Berrettini M., Gabryelak T. \& Falcioni G. 2004. The effect of some tannins on trout erythrocytes exposed to oxidative stress. Mutation Research/Fundamental and Molecular Mechanisms of Mutagenesis. 563(2): 89-96.

12 Haile A., Tembely S. \& Anindo D.O. 2002. Effects of breed and dietary protein supplementation on the responses to gastrointestinal nematode infections in Ethiopian sheep. Small Ruminant Research. 44(2): 247-261.

13 Hervás G., Pérez V., Giraldez F.J., Mantecón A.R., Almar M.M. \& Frutos P. 2003. Intoxication of sheep with quebracho tannin extract. Journal of Comparative Pathology. 129(1): 44-54.

14 Jefferies B.C. 1961. Body condition scoring and its use in management. Tasmanian Journal Agricultural. 32(1): 19-21.

15 Kamel H.E.M., Al-Dobaib S.N., Salem A.Z.M., López S. \& Alaba P.A. 2018. Influence of dietary supplementation with sunflower oil and quebracho tannins on growth performance and meat fatty acid profile of Awassi lambs. Animal Feed Science and Technology. 235(1): 97-104.

16 Liu H., Li K., Mingbin L., Zhao J. \& Xiong B. 2016. Effects of chestnut tannins on the meat quality, welfare, and antioxidant status of heat-stressed lambs. Meat Science. 116(2): 236-242.

17 Lobón S., Sanz A., Blanco M., Ripoll G. \& Joy M. 2017. The type of forage and condensed tannins in dams' diet: Influence on meat shelf life of their suckling lambs. Small Ruminant Research. 154(1): 115-122.

18 Makkar H.P.S. 2003. Effects and fate tannins in ruminant animals, adaptation to tannins, and strategies to overcome detrimental effects of feeding tannin-rich feeds. Small Ruminant Research. 49(2): 241-156.

19 Min B.R., Barry T.N., Attwood G.T. \& McNabb W.C. 2003. The effect of condensed tannins on the nutrition and health of ruminants fed fresh temperate forages: a review. Animal Feed Science and Technology. 105(1): 3-10.

20 Molento M.B., Tasca C., Gallo A., Ferreira M., Bononi R. \& Stecca E. 2004. Método Famacha como parâmetro clínico individual de infecção por Haemonchus contortus em pequenos ruminantes. Ciência Rural. 34(10): 1139-1145.

21 Monteiro J.M. 2005. Taninos: Uma abordagem da química à ecologia. Quimica Nova. 28(6): 892-896.

22 NRC - National Research Council. 2007. Nutrient Requirements of Small Ruminants: Sheep, Goats, Cervids, and New World Camelids. Washington, DC: The National Academies Press, 384p. 
23 Olchowik E., Lotkowski K., Mavlyanov S., Abdullajanova N., Ionov M., Bryszewska M. \& Zamaraeva M. 2012. Stabilization of erythrocytes against oxidative and hypotonic stress by tannins isolated from sumac leaves (Rhus typhina L.) and grape seeds (Vitis vinifera L.). Cellular \& Molecular Biology Letters. 17(3): 333-348.

24 Osório J.C.S., Osório M.T. \& Oliveira N.M. 2003. Morfologia, características da carcaça e componentes do peso vivo em borregos Corriedale e Ideal. Ciência Rural. 33(2): 351-355.

25 Otero M.J. \& Hidalgo L.G. 2004. Taninos condensados en especies forrajeras de clima templado: efectos sobre la productividad de rumiantes afectados por parasitosis gastrointestinales (uma revisión). Livestock Research for Rural Development 16(1): 1-9.

26 Paolini V., Frayssines A., De La Farge F., Dorchies P. \& Hoste H. 2003. Effects of condensed tannins on established populations and on incoming larvae of Trichostrongylus colubriformis and Teladorsagia circumcincta in goats. Veterinary Research 34(2): 331-339.

27 Rivera-Méndez C., Plascencia A., Torrentera N. \& Zinn R. A. 2017. Effect of level and source of supplemental tannin on growth performance of steers during the late finishing phase. Journal of Applied Animal Research. 45(2): 199-203.

28 Van Soest P.J. 1994. Nutritional ecology of the ruminant. Ithaca: Cornell University Press, pp.203-207.

29 Villas Bôas A.S., Arrigoni M.B., Silveira A.C., Costa C. \& Chardulo L.A.L. 2003. Effects of age at weaning and feed management on the production of super-young lambs. Revista Brasileira de Zootecnia. 32(9): 1969-1980.

30 Valenti B., Natalello A., Vasta V., Campidonico L., Roscini V., Mattioli S. \& Luciano G. 2019. Effect of different dietary tannin extracts on lamb growth performances and meat oxidative stability: Comparison between mimosa, chestnut and tara. Animal. 13: 435-443. 